\section{Response of Hybrid Bermudagrass and Manilagrass to Soil Moisture Using Water-table Depth Gradient Tanks}

\author{
Gerald Henry \\ Department of Crop and Soil Sciences, University of Georgia, 3111 \\ Miller Plant Science Building, Athens, GA 30602
}

\author{
Rebecca Grubbs \\ Department of Soil and Crop Sciences, Texas A\&M University, 17360 \\ Coit Road, Dallas, TX 75252
}

\section{Chase Straw}

Department of Soil and Crop Sciences, Texas A\&M University, 370 Olsen Blvd, College Station, TX 77843

\section{Kevin Tucker \\ Department of Crop and Soil Sciences, University of Georgia, 3111 Miller Plant Science Building, Athens, GA 30602}

\section{Jared Hoyle \\ Corteva Agriscience, Manhattan, KS 66506}

Additional index words. canopy temperature, greenhouse, normalized difference vegetation index, root biomass, turfgrass quality, volumetric water content

\begin{abstract}
Previous research involving turfgrass response to soil moisture used methodology that may compromise root morphology or fail to control outside environmental factors. Water-table depth gradient tanks were employed in the greenhouse to identify habitat specialization of hybrid bermudagrass [Cynodon dactylon (L.) Pers. $\times C$. transvaalensis Burtt-Davy] and manilagrass [Zoysia matrella (L.) Merr.] maintained at 2.5 and $5.1 \mathrm{~cm}$. Turfgrass quality (TQ), normalized difference vegetation index (NDVI), canopy temperature (CT), and root biomass (RB) were used as metrics for plants grown in monoculture in sandy clay loam soil. Mowing height did not affect growth of turfgrass species in response to soil moisture. Turfgrass quality, NDVI, and RB were greatest, whereas CT was lowest at wetter levels [27- to $58-\mathrm{cm}$ depth to the water-table (DWT)] of each tank where plants were growing at or above field capacity. However, bermudagrass RB was greatest at 27-cm DWT, whereas manilagrass RB at 27-cm DWT was lower than RB at 42.5- to 73.5-cm DWT in 2013 and lower than all other levels in 2014. Both species responded similarly to droughty levels (120to 151-cm DWT) of the tanks. Turfgrass quality, NDVI, and RB were lowest, whereas CT was highest at higher droughty levels. Bermudagrass may be more competitive than manilagrass when soil moisture is high whereas both species are less competitive when soil moisture is low.
\end{abstract}

The effects of drought and water conservation efforts on turfgrass quality have been well documented for arid and semiarid regions (Culpepper et al., 2020; Garrot and Mancino, 1994; Kneebone and Pepper, 1982;

Received for publication 10 Mar. 2021. Accepted for publication 8 June 2021.

Published online 5 August 2021

We thank the Georgia Golf Environmental Foundation funded by the Georgia Golf Course Superintendents Association for financial support of this research project. We also thank the numerous undergraduate student workers for their assistance with experimental setup, maintenance, and data collection in the greenhouse.

G.H. is the corresponding author. E-mail: gmhenry@uga.edu.

This is an open access article distributed under the CC BY-NC-ND license (https://creativecommons. org/licenses/by-nc-nd/4.0/). while maintaining quality may provide a partial solution to this specific problem.

Hybrid bermudagrass [Cynodon dactylon (L.) Pers. $\times$ C. transvaalensis Burtt-Davy] and manilagrass [Zoysia matrella (L.) Merr.] are two of the primary warm-season turfgrass species used for home lawns, athletic fields, and golf courses in the southeastern United States (Christians et al., 2016; Turgeon, 2011). Previous research examining the response of turfgrass species to soil moisture has predominantly focused on field and container studies that are limited in their design and implementation (Aronson et al., 1987; Carrow, 1996; Hook and Hanna, 1994; Huang and Gao, 2000; Huang et al., 1997a; Marcum et al., 1995; Qian and Fry, 1997; Qian et al., 1997; Zhou et al., 2012). These studies clearly demonstrated variability in drought response based on turfgrass selection and cultural management practices. However, specific findings are inconsistent and fairly contradictory, further supporting the need for additional research and alternative experimental designs.

Water stress symptomology typically manifests as reduced shoot growth, desiccation and wilting of leaf tissue, and an overall loss of turfgrass quality as a result of compromised cellular growth, root stress, and increased root mortality (Fry and Huang, 2004). Turfgrasses often employ drought avoidance mechanisms including investment in below-ground tissue to maximize water uptake and above-ground tissue to maximize transpiration (Carrow, 1996; Hays et al., 1991; Huang et al., 1997b; Qian et al., 1997). Bermudagrass (Cynodon spp.) generally tolerates higher temperatures and limited water resources better than other turfgrass species (McCarty et al., 2011; Wherley et al., 2014). This may be attributed to the production of a deeper, more extensive root system and aggressive, hardy rhizomes (Duble, 2001). Although zoysiagrass (Zoysia spp.) often produces a shallower root system, intraspecific variability in rooting response has been reported (Zhang et al., 2013). Additionally, Qian and Fry (1997) speculate that leaf rolling along with reduced leaf extension in zoysiagrass may act as an additional drought avoidance mechanism by increasing leaf and canopy boundary layer resistance to evapotranspiration (ET).

Mowing is one of the most basic cultural practices performed on turfgrass environments and can have a major effect on water use efficiency (Harivandi and Gibeault, 1990; Shahba et al., 2014; Wherley et al., 2014). The periodic removal of a portion of shoot growth increases stress on turfgrass plants. This stress significantly affects the ability of turfgrass to withstand abiotic and biotic pressure by inhibiting photosynthetic activity, limiting carbohydrate production and storage, reducing water uptake, and compromising lateral growth (Fry and Huang, 2004). Removal of the cuticle during mowing can also introduce pathogenic stress and lead to increased evaporative losses (Turgeon, 2011). Higher mowing heights typically support deeper, more vigorous roots that have access to larger water reservoirs within the soil profile (Christians et al., 2016). 
However, increased vegetative material has been found to increase ET rates and ultimately increase plant water requirements (Biran et al., 1981; Feldhake et al., 1983, 1984). Minimal research has examined the interaction of soil moisture and mowing height on bermudagrass and zoysiagrass growth and turfgrass quality. Wherley et al. (2014) investigated the response of zoysiagrass to mowing height and soil moisture using a linear gradient irrigation system (LGIS) but only observed variability among cultivars. Culpepper et al. (2020) compared natural rainfall vs. supplemental irrigation and observed differential responses with respect to turfgrass species but not mowing height.

A variety of experimental approaches has been employed to evaluate the response of plants to soil moisture. Each of these systems presents unique challenges to providing a comprehensive view of plant-water relations. Container studies that used drip irrigation and partial wetting of the upper soil profile to examine cotton (Gossypium hirsutum L.) growth revealed significant disruptions in natural root distribution and restrictions in rooting volume within the plastic cylinders (Plaut et al., 1996). Krizek et al. (1985) suggested that root restriction commonly observed in pot studies can mimic the effect of soil moisture stress even when sufficient moisture is present for normal plant growth. Furthermore, Carrow (1996) established intraspecific and interspecific variability in root response to drought at depths between 20 and $60 \mathrm{~cm}$, asserting that evaluation of deep rooting is critical in determining total drought response. Containers that significantly limit root depth under water deficit may not provide a complete illustration of plant response to soil moisture, particularly for deep-rooting species such as bermudagrass. In recent years, several studies have used LGIS in the field to evaluate turfgrass response to soil moisture (Qian and Engelke, 1999; Wherley et al., 2014; Zhang et al., 2013, 2015). Although LGIS create a continuous and complete moisture gradient, this approach is often subject to environmental variables including precipitation, wind disruption, and malfunctioning irrigation heads. Mueller-Dombois and Sims (1966) developed an alternative method that avoids several of these shortcomings. This approach uses water-table depth gradient tanks that promote natural capillary rise of soil water and offer the opportunity for surface irrigation to simulate rainfall. However, a large amount of greenhouse space, labor, and materials are required to build and house these tanks on site. Furthermore, growing turfgrass on slopes limits establishment to sod, sprigs, or plugs. A standpipe in the front of the tank regulates the water-table depth, whereas capillary rise keeps the low end of the tank at field capacity. Plants are subjected to progressively lower soil moisture levels and greater depth to the water-table when grown at higher elevations of the tank. This methodology allows investigators to measure reduction in turfgrass quality/growth characteristics in response to irrigation restrictions and mowing height on native soil within a controlled environment. Therefore, the objective of our research was to evaluate the response of hybrid bermudagrass and manilagrass to a soil moisture gradient and mowing height using water-table depth gradient tanks.

\section{Materials and Methods}

Experimental setup and maintenance. Four water-table depth gradient tanks were constructed at the Crop and Soil Sciences greenhouse complex in Athens, GA (lat. $33^{\circ} 55^{\prime} \mathrm{N}$, long. $83^{\circ} 21^{\prime} \mathrm{W}$ ) during Summer 2013 (modified from Henry et al., 2009; Mueller-Dombois, 1965; Mueller-Dombois and Sims, 1966). Tanks were steeply sloped $(63 \%)$ and oriented to the south. The tanks measured $2.4 \mathrm{~m}$ long, $1.2 \mathrm{~m}$ wide, and were $0.3 \mathrm{~m}$ high at one end and $1.8 \mathrm{~m}$ high at the other end with a volume of nearly $4 \mathrm{~m}^{3}$ (Fig. 1A). Each tank was lined with a double layer of $0.076-\mathrm{mm}$ (3-mil) black plastic and had a $25-\mathrm{cm}$ base of pea gravel to provide a uniform substrate for water movement. The pea gravel was covered with $3 \mathrm{~cm}$ of coarse sand to reduce soil movement into the gravel layer. All four tanks were filled with a steamed 2:1 mixture of Cecil sandy clay loam (fine, kaolinitic, thermic Typic Kanhapludults) and Wakulla sand (siliceous, thermic Psammentic Hapludults) with a soil $\mathrm{pH}$ of 5.8 and organic matter content of $1.2 \%$. Overhead irrigation was applied by hand every other day over the surface of each tank to facilitate the settling of the soil before sod transplant. A $1.9-\mathrm{cm}$ valve at the high end of the tank regulated water inflow, and a standpipe $(2.5-\mathrm{cm}$ diameter) at the low end of the tank regulated the watertable height. Tank surfaces were divided into nine levels of depth to the water-table (DWT): 27.0 (level 1), 42.5, 58.0, 73.5, 89.0, 104.5, $120.0,135.5$, and $151.0 \mathrm{~cm}$ (level 9).

Turfgrass species (hybrid bermudagrass or manilagrass) were randomly assigned to tank pairs at the beginning of each experimental run. Hybrid bermudagrass ('Tifway 419') and manilagrass ('Zeon') sod (1-year-old) were transplanted on 5 June 2013 and 13 Jan. 2014. Soil was washed from sod before transplant to encourage rooting and discourage layering of contrasting soil textures. A starter fertilizer $(18 \mathrm{~N}-4 \mathrm{P}-15 \mathrm{~K})$ (The Andersons Lawn Fertilizer Inc., Maumee, $\mathrm{OH}$ ) was applied at transplant with follow-up application during establishment at a rate of $49 \mathrm{~kg} \cdot \mathrm{ha}^{-1} \mathrm{~N}$. Surface irrigation provided through hand-watering was employed every other day $\left(0.4 \mathrm{~cm} \cdot \mathrm{d}^{-1}\right)$ for $\approx 12$ wk during sod establishment to give a greater opportunity for uniform recruitment (stopped on 29 Aug. 2013 and 6 Apr. 2014) and occasionally thereafter to prevent wilting. Tap water was used for both surface and groundwater. Natural light was supplemented with artificial light at $500 \mu \mathrm{mol} \cdot \mathrm{m}^{-2} \cdot \mathrm{s}^{-1}$ photosynthetic photon flux in a $12-\mathrm{h}$ day to approximate summer light intensity and photoperiod. Conditions in the greenhouse were maintained at day/night temperatures of $32 / 24^{\circ} \mathrm{C}$. All gradient tanks were mowed once a week using sheep shearers (Oster Professional Products, McMinnville, TN) to a height of $3.8 \mathrm{~cm}$. Tanks were divided in half vertically 2 weeks before trial establishment. Mowing treatments ( 2.5 or $5.1 \mathrm{~cm}$ ) were randomly assigned to each tank. Each mowing treatment was gradually reduced or increased over the next 2 weeks until they reached desired mowing heights. Mowing treatments were chosen to represent golf course rough and home lawn heights and provide optimal differences in canopy height. Soil cores (2.5- $\mathrm{cm}$ diameter) were removed from several levels of each tank to check rooting uniformity at the initiation of the study (29 Aug. 2013 and 6 Apr. 2014). Each experiment was a splitblock design with two replications.

Capillary rise was determined at the conclusion of each trial by excavating the soil profile with a hand trough in three locations (left, center, and right of the tank) at each level and measuring moisture with a FieldScout TDR 300 Soil Moisture Meter (Spectrum Technologies Inc., Aurora, IL) equipped with two probes ( $7.6 \mathrm{~cm}$ long) spaced $3.3 \mathrm{~cm}$ apart. Soil moisture readings were conducted every $5.1 \mathrm{~cm}$ down the inside of each excavated shaft until readings reached field capacity. Soil moisture profiles for all four tanks were similar; therefore, readings were averaged to create a profile of the capillary fringe (Fig. 1B). The capillary fringe of hybrid bermudagrass and manilagrass tanks rose $\approx 81$ $\mathrm{cm}$ from the water table. Percent volumetric water content (VWC) was $21.2 \%, 10.6 \%$, $3.1 \%, 0 \%$, and $0 \%$ in the upper $7.6 \mathrm{~cm}$ of the soil profile for levels $1,3,5,7$, and 9, respectively. Therefore, a gradual change in soil moisture near the surface was recorded from level 1 to level 9 in each tank, regardless of turfgrass species.

Data acquisition. TQ, plant health measured as NDVI, CT, and RB were determined at the conclusion of each trial (26 Nov. 2013 and 6 July 2014). Visual ratings of TQ were recorded on a scale of 1 to 9 with a rating of 6 considered acceptable TQ (Morris and Shearman, 2007). Plant health was recorded with a Field Scout CM 1000 NDVI chlorophyll meter (Spectrum Technologies Inc., Aurora, IL). A vegetative index [ $\{\mathrm{NDVI}=$ $[(\mathrm{R} 770-\mathrm{R} 660) /(\mathrm{R} 770+\mathrm{R} 660)\}]$ was calculated ( 0 to 1 , where 1 is best) from the reflectance readings. An average of three readings were obtained per DWT level per mowing treatment in each tank. Canopy temperature $\left({ }^{\circ} \mathrm{C}\right)$ was recorded using an Oakton TempTester IR thermometer (OAKTON Instruments, Vernon Hills, IL). An average of three readings were obtained per DWT level per mowing treatment in each tank. A $10.2-\mathrm{cm}$ golf course cup-cutter was used to remove the above-ground biomass and corresponding root system together as a plug (to a depth of $20.3 \mathrm{~cm}$ ) in three locations per DWT level per mowing treatment in each tank at the conclusion of each trial. Roots were washed, separated from above-ground tissue, dried in an oven at $50{ }^{\circ} \mathrm{C}$ for $7 \mathrm{~d}$, and weighed to determine biomass (grams).

Statistical analysis. This study was replicated over time by performing two experimental runs. Homogeneity of variance of data were confirmed by plotting residuals 


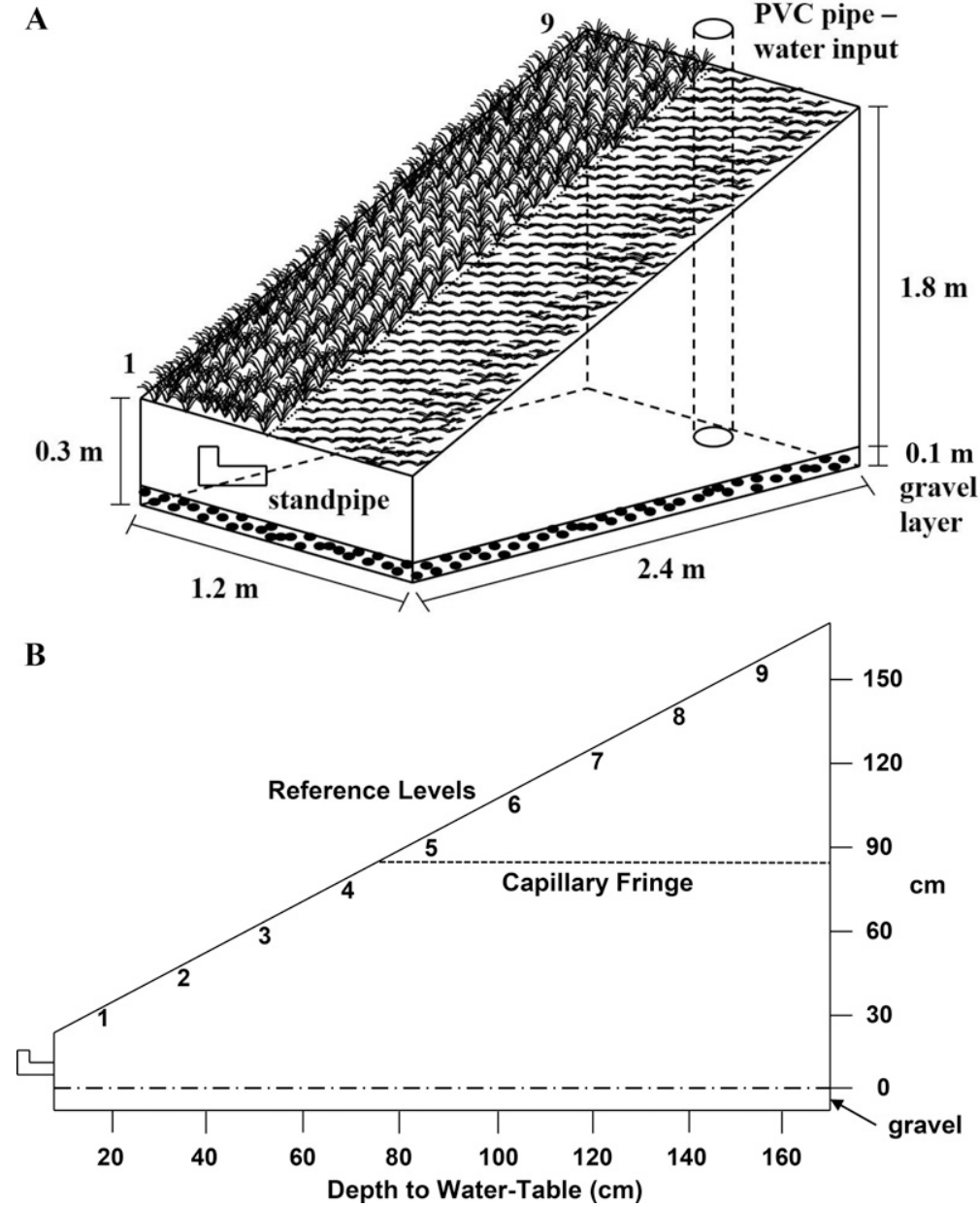

Fig. 1. (A) Schematic of water-table depth gradient tank construction (... represents the division between mowing heights). (B) Cross section through a tank showing the capillary fringe. PVC = polyvinyl chloride.

Analysis of variance (ANOVA) was performed separately for hybrid bermudagrass and manilagrass. ANOVA was conducted using the Mixed procedure to conduct both split-plot and autoregressive (to control for possible autocorrelation of soil moisture levels, which could not be randomized; Bivand, 1980; Cliff and Ord, 1981) analyses (SAS Institute, Cary, NC). In the split-plot analysis, turfgrass species was treated as the wholeplot and mowing height as the subplot factor, whereas soil moisture level was considered a stripped factor. Similar analytical structure was used in the autoregressive model analyses. Study repetition was considered a random factor. Correlation coefficients were calculated using the PROC CORR function in SAS to determine the strength and direction of relationship between all measured plant and soil properties (Clifford et al., 1989; Dutilleul, 1993). Linear regression was performed on the data using SigmaPlot 12.5 (Systat Software, San Jose, CA) to evaluate the response of hybrid bermudagrass and manilagrass to DWT levels.

\section{Results}

Correlation coefficients $(r)$ evaluating the relationships between TQ, NDVI, CT, RB, and
DWT for hybrid bermudagrass and manilagrass are presented in Table 1 and Table 2, respectively. There were strong, significant relationships between all parameters with the exception of $\mathrm{RB}$, which did not consistently correlate to any other variable for either hybrid bermudagrass or manilagrass. No significant effect of mowing height was observed for either species, so data were pooled across mowing heights to evaluate individual species response to soil moisture gradient levels (DWT). in 2013 and 2014.
Hybrid bermudagrass response. Turfgrass quality was negatively correlated to $\mathrm{CT}$ (2013, $r=-0.71 ; 2014, r=-0.76)$ and DWT (2013, $r=-0.56 ; 2014, r=-0.82$ ), but positively correlated to NDVI (2013, $r=$ $0.85 ; 2014, r=0.76)$. Mean separation for TQ with respect to DWT for hybrid bermudagrass was evaluated separately for 2013 and 2014 due to a significant year effect $(P<$ $0.001)$. No significant interaction was observed between mowing height and TQ response to DWT $(P=0.375)$. Mean TQ never reached acceptable levels for 2013 but still demonstrated a discernible response to soil moisture gradient levels. Highest TQ ratings in 2013 were observed at 42.5- and 89$\mathrm{cm}$ DWT $(\overline{\mathrm{x}}=5.8$ and 5.5 , respectively $)$ with slightly lower TQ ratings at 27, 58, 73.5, and $104.5-\mathrm{cm}$ DWT. Turfgrass quality progressively declined with increasing DWT. Statistically significant decreases were reported at 120-cm DWT and again at 135.5- and 151cm DWT $(P=0.01)$. Similarly, TQ for 2014 reached acceptable levels at $27-$ and $42.5-\mathrm{cm}$ DWT ( $\overline{\mathrm{x}}=6.0$ and 6.3 , respectively) with the lowest TQ at 135.5- and 151-cm DWT $(\overline{\mathrm{x}}=$ 1.8 and 1.3 , respectively). Simple linear regression models predicting TQ with respect to DWT are shown in Fig. 2A. Goodness of fit was stronger in $2014\left(R^{2}=0.93\right)$ than $2013\left(R^{2}=0.69\right)$.

Correlations between NDVI and other parameters can be found in Table 1. Normalized difference vegetation index positively correlated with $\mathrm{TQ}$, but negatively correlated with CT (2013, $r=-0.77 ; 2014, r=-0.69$ ) and DWT (2013, $r=-0.80 ; 2014, r=$ -0.62 ). No significant differences in NDVI were found across years or across mowing heights $(P=0.221$ and $P=0.413$, respectively); therefore, data were pooled for comparison at each soil moisture gradient level. The highest NDVI ratings were observed at 27-, 42.5-, 58-, and 104.5-cm DWT $(\overline{\mathrm{x}}=$ $0.71,0.67,0.67$, and 0.65 , respectively). Although data for NDVI at 73.5- and 89-cm DWT were slightly lower $(\overline{\mathrm{x}}=0.62)$ (not statistically significant), canopy density and color remained relatively uniform for hybrid bermudagrass up to 104.5-cm DWT. A gradual decline in NDVI was observed with increasing DWT $(\overline{\mathrm{x}} 120 \mathrm{~cm}=0.55 ; \overline{\mathrm{x}} 135.5$

Table 1. Correlation coefficients among turfgrass quality (TQ), normalized difference vegetation index (NDVI), canopy temperature (CT), root biomass (RB), and depth to water-table (DWT) for 'Tifway 419' hybrid bermudagrass [Cynodon dactylon (L.) Pers. $\times$ C. transvaalensis Burtt-Davy]

\begin{tabular}{|c|c|c|c|c|c|}
\hline & TQ & NDVI & CT $\left({ }^{\circ} \mathrm{C}\right)$ & RB (g) & DWT $(\mathrm{cm})$ \\
\hline \multicolumn{6}{|c|}{2013} \\
\hline TQ & 1 & $0.85 * * *$ & $-0.71 * * *$ & 0.26 & $-0.56 * * *$ \\
\hline NDVI & & 1 & $-0.77 * * *$ & $0.42 * * *$ & $-0.80 * * *$ \\
\hline $\mathrm{CT}\left({ }^{\circ} \mathrm{C}\right)$ & & & 1 & $-0.37^{*}$ & $0.66^{* * *}$ \\
\hline RB (g) & & & & 1 & $-0.52 * * *$ \\
\hline DWT $(\mathrm{cm})$ & & & & & 1 \\
\hline \multicolumn{6}{|c|}{2014} \\
\hline TQ & 1 & $0.76^{* * *}$ & $-0.76^{* * *}$ & $0.47 * *$ & $-0.82 * * *$ \\
\hline NDVI & & 1 & $-0.69 * * *$ & 0.13 & $-0.62 * * *$ \\
\hline $\mathrm{CT}\left({ }^{\circ} \mathrm{C}\right)$ & & & 1 & -0.14 & $0.87 * * *$ \\
\hline $\mathrm{RB}(\mathrm{g})$ & & & & 1 & -0.21 \\
\hline DWT $(\mathrm{cm})$ & & & & & 1 \\
\hline
\end{tabular}

Significant correlations $\left({ }^{*} P<0.05,{ }^{*} P<0.01\right.$, and $\left.{ }^{* * *} P<0.001\right)$. 
Table 2. Correlation coefficients among turfgrass quality (TQ), normalized difference vegetation index (NDVI), canopy temperature (CT), root biomass (RB), and depth to water-table (DWT) for 'Zeon' manilagrass [Zoysia matrella (L.) Merr.].

\begin{tabular}{|c|c|c|c|c|c|}
\hline & TQ & NDVI & $\mathrm{CT}\left({ }^{\circ} \mathrm{C}\right)$ & $\mathrm{RB}(\mathrm{g})$ & DWT $(\mathrm{cm})$ \\
\hline \multicolumn{6}{|c|}{2013} \\
\hline TQ & 1 & $0.93 * * *$ & $-0.67 * * *$ & $0.57 * * *$ & $-0.85^{* * *}$ \\
\hline NDVI & & 1 & $-0.76^{* * *}$ & $0.68^{* * *}$ & $-0.87 * * *$ \\
\hline $\mathrm{CT}\left({ }^{\circ} \mathrm{C}\right)$ & & & 1 & $-0.42 *$ & $0.79 * * *$ \\
\hline RB (g) & & & & 1 & $-0.52 * * *$ \\
\hline DWT $(\mathrm{cm})$ & & & & & 1 \\
\hline \multicolumn{6}{|c|}{2014} \\
\hline TQ & 1 & $0.94 * * *$ & -0.89 *** & 0.14 & $-0.89 * * *$ \\
\hline NDVI & & 1 & $-0.82 * * *$ & 0.14 & $-0.77 * * *$ \\
\hline $\mathrm{CT}\left({ }^{\circ} \mathrm{C}\right)$ & & & 1 & -0.15 & $0.91 * * *$ \\
\hline RB (g) & & & & 1 & 0.01 \\
\hline DWT $(\mathrm{cm})$ & & & & & 1 \\
\hline
\end{tabular}

Significant correlations $\left({ }^{*} P<0.05,{ }^{* *} P<0.01\right.$, and $\left.{ }^{* * *} P<0.001\right)$.

$\mathrm{cm}=0.46 ; \overline{\mathrm{x}} 151 \mathrm{~cm}=0.39)$. The negative relationship between NDVI and DWT was modeled linearly with an $R^{2}$ value of 0.83 (Fig. 2B).

Canopy temperature was negatively correlated to TQ and NDVI, but positively correlated to DWT (2013, $r=0.66 ; 2014, r=$ $0.87)$. There was no significant effect of mowing height $(P=0.323)$; therefore, data were pooled across mowing heights. Mean separation for CT with respect to DWT was evaluated separately for 2013 and 2014 due to a significant year effect $(P<0.001)$. The lowest CT for 2013 was observed at 27- and 73.5-cm DWT (23.2 and $23.7^{\circ} \mathrm{C}$, respectively) with only slight increases in $\mathrm{CT}$ at 42.5-, 58-, and 89-cm DWT (not statistically significant). Canopy temperature continued to increase with increasing DWT. The highest CTs were recorded at $135.5-$ and $151-\mathrm{cm}$ DWT $\left(27.3\right.$ and $27.5^{\circ} \mathrm{C}$, respectively). There was a similar increase in $\mathrm{CT}$ with increasing DWT for 2014. Average CT was lowest at $27-\mathrm{cm}$ DWT $\left(23.8^{\circ} \mathrm{C}\right)$ and gradually increased to the highest CTs between 104.5- and 151-cm DWT, peaking at $32.5^{\circ} \mathrm{C}$. Predictive modeling of the relationship between $\mathrm{CT}$ and DWT for each experimental run confirmed positive linear relationships. Canopy temperature had a stronger relationship with DWT in $2014\left(R^{2}=0.94\right)$ than in $2013\left(R^{2}=0.88\right)$ (Fig. 2C).

Significant relationships between RB and other variables (TQ, NDVI, CT, or DWT) were not consistent. In 2013, a moderately positive correlation was observed with NDVI $(r=0.42)$, but a moderately negative correlation was observed with CT $(r=-0.37)$ and DWT $(r=-0.52)$. In 2014, only a moderately positive correlation was observed with TQ $(r=0.47)$. Mean separation for RB with respect to DWT were pooled across experimental runs and mowing heights $(P=0.336$ and $P=0.287$, respectively). Significant differences between gradient levels did exist, with greatest RB at 27-, 42.5-, and 58-cm DWT $(\overline{\mathrm{x}}=0.83 \mathrm{~g}, \overline{\mathrm{x}}=1.05 \mathrm{~g}$, and $\overline{\mathrm{x}}=0.75 \mathrm{~g}$, respectively) $(P=0.02)$. Root biomass measurements were slightly lower for 73.5-, 89-, 104.5-, 135.5-, and 151-cm DWT but were statistically similar to $27-$ and $58-\mathrm{cm}$ DWT. The lowest RB was reported for $120-\mathrm{cm}$ DWT $(\overline{\mathrm{x}}=$ $0.43 \mathrm{~g}$ ). Linear regression models predicting RB with respect to DWT are shown in Fig. 2D $\left(R^{2}=0.60\right)$.

Manilagrass response. Turfgrass quality showed a strong positive relationship to NDVI (2013, $r=0.93 ; 2014, r=0.94)$, but strong negative relationships to CT (2013, $r=-0.67 ; 2014, r=-0.89)$ and DWT
A

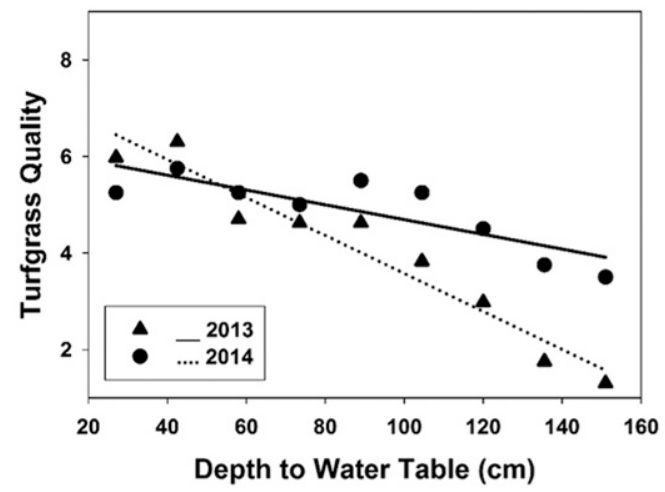

C

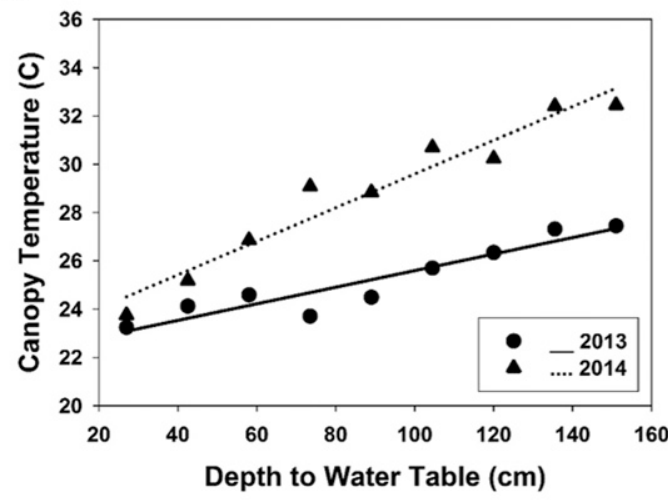

B

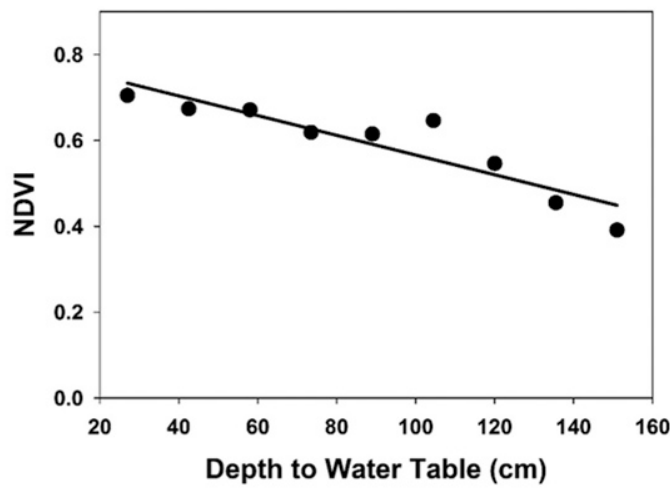

D

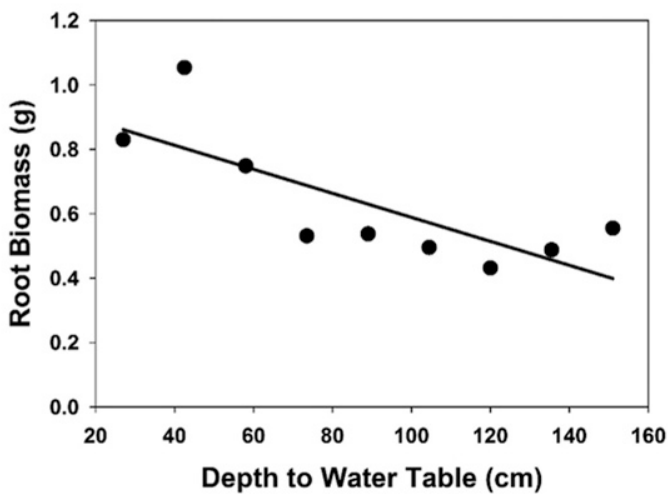

Fig. 2. 'Tifway 419' hybrid bermudagrass [Cynodon dactylon (L.) Pers. $\times$ C. transvaalensis Burtt-Davy] response to soil moisture levels: turfgrass quality (TQ) (A), normalized difference vegetation index (NDVI) (B), canopy temperature (CT) (C), and root biomass (RB) (D). Linear equations: TQ 2013, $\mathrm{y}=6.225-0.015 \mathrm{x}, R^{2}=0.69 ; \mathrm{TQ} 2014, \mathrm{y}=7.511-0.039 \mathrm{x}, R^{2}=0.93 ; \mathrm{NDVI}, \mathrm{y}=0.796-0.002 \mathrm{x}, R^{2}=0.83 ; \mathrm{CT} 2013, \mathrm{y}=22.16+0.034 \mathrm{x}, R^{2}=$ $0.88 ;$ CT $2014, \mathrm{y}=22.62+0.069 \mathrm{x}, R^{2}=0.94 ; \mathrm{RB}, \mathrm{y}=0.962-0.003 \mathrm{x}, R^{2}=0.60$. 
A

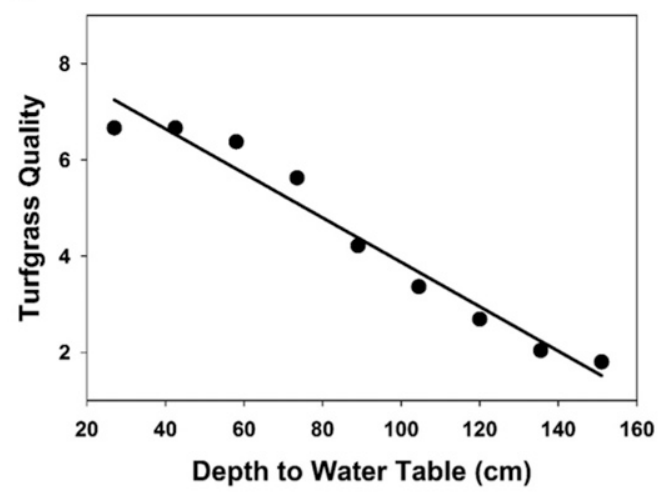

C

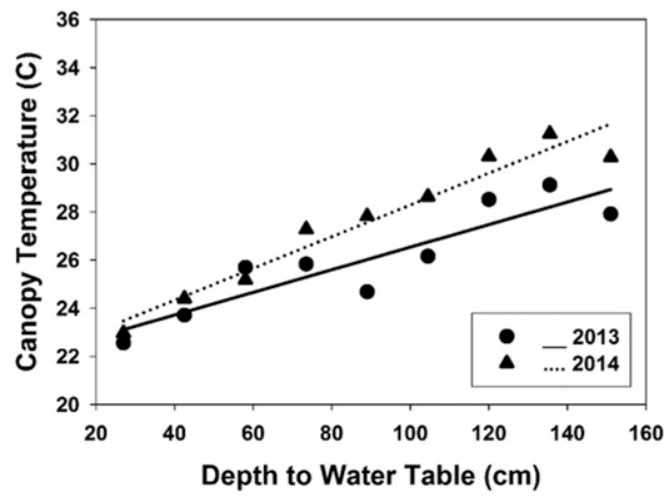

B

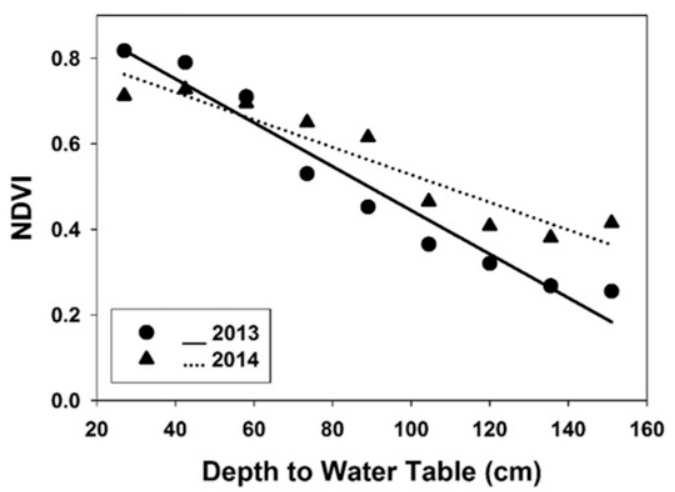

D

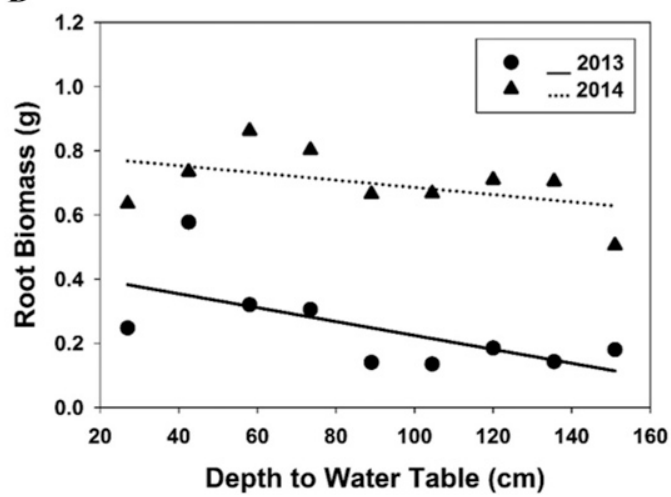

Fig. 3. 'Zeon' manilagrass [Zoysia matrella (L.) Merr.] response to soil moisture levels using water-table depth gradient tanks: turfgrass quality (TQ) (A), normalized difference vegetation index (NDVI) $(\mathbf{B})$, canopy temperature $(\mathrm{CT})(\mathbf{C})$, and root biomass (RB) $(\mathbf{D})$. Linear equations: TQ, y $=8.492-$ $0.046 \mathrm{x}, R^{2}=0.96$; NDVI 2013, y $=0.956-0.005 \mathrm{x}, R^{2}=0.95 ;$ NDVI 2014, $\mathrm{y}=0.849-0.003 \mathrm{x}, R^{2}=0.90 ; \mathrm{CT} 2013, \mathrm{y}=21.84+0.047 \mathrm{x}, R^{2}=$ 0.82 ; CT 2014, y $=21.69+0.066 \mathrm{x}, R^{2}=0.94 ; \mathrm{RB} 2013, \mathrm{y}=0.441-0.002 \mathrm{x}, R^{2}=0.42 ; \mathrm{RB} 2014, \mathrm{y}=0.799-0.001 \mathrm{x}, R^{2}=0.22$

(2013, $r=-0.85 ; 2014, r=-0.89$ ). Mean separation for TQ with respect to DWT for manilagrass was pooled across years and mowing heights $(P=0.197$ and $P=0.294$, respectively). The highest TQ ratings were observed between levels $27-$ to $73.5-\mathrm{cm}$ DWT with acceptable TQ $(\overline{\mathrm{x}} \geq 6)$ from 27 to $58-\mathrm{cm}$ DWT. Turfgrass quality declined to unacceptable ratings with increasing DWT. The lowest ratings were reported at 135.5and $151-\mathrm{cm}$ DWT $(\overline{\mathrm{x}}=2.0$ and 1.8 , respectively). A linear regression model using DWT to predict TQ confirmed a strong negative relationship $\left(R^{2}=0.96\right)$ (Fig. 3A).

Normalized difference vegetation index showed a strong positive relationship to TQ, but strong negative relationships to CT (2013, $r=-0.76 ; 2014, r=-0.82)$ and DWT (2013, $r=-0.87$; 2014, $r=-0.77$ ). There was no significant effect of mowing height; therefore, data were pooled across mowing heights $(P=0.224)$. Mean separation for NDVI with respect to DWT was performed separately for 2013 and 2014 due to a significant year effect $(P=0.01)$. There were more significant differences between gradient levels in $2013(P=0.004)$ than in $2014(P=$ $0.03)$. In 2013 , the highest mean NDVI $(\overline{\mathrm{x}}=$ $0.82)$ was found at the lowest DWT $(27-\mathrm{cm}$ DWT) with a gradual decrease with increasing DWT and the lowest mean NDVI ( $\overline{\mathrm{x}}=$ 0.26 ) at $151-\mathrm{cm}$ DWT. A similar trend was established in 2014 with higher mean NDVI readings at lower DWT. However, the highest NDVI for 2014 was observed at $42.5-\mathrm{cm}$ DWT $(\overline{\mathrm{x}}=0.73)$ with slightly lower values at 27-, 58-, and 73.5-cm DWT (not statistically significant). As DWT increased, NDVI decreased significantly, first at 89-cm DWT and then reached its lowest levels between 104.5- and 151-cm DWT, but never dropping below $\overline{\mathrm{x}}=0.38$. Linear regression models predicting NDVI with respect to DWT are shown in Fig. 3B. For both 2013 and 2014 data, strong negative trends were observed $\left(R^{2}=0.95\right.$ and $R^{2}=0.90$, respectively).

Canopy temperature showed strong negative relationships to TQ and NDVI but a strong positive relationship to DWT (2013, $r=0.79 ; 2014, r=0.91)$. There was no significant effect of mowing height; therefore, data were pooled across mowing heights $(P=0.368)$. Mean separation for $\mathrm{CT}$ with respect to DWT was performed separately for 2013 and $2014(P=0.02)$. General trends were consistent for both years, showing clear positive trends with CT increasing with increasing DWT. In 2013 and 2014, lowest CTs were both observed at 27-cm DWT ( $\mathrm{x}=$ $22.5^{\circ} \mathrm{C}$ and $23^{\circ} \mathrm{C}$, respectively). Alternatively, the highest CTs were observed at 120and $135.5-\mathrm{cm}$ DWT for both years, peaking at $29.1^{\circ} \mathrm{C}$ in 2013 and $31.3^{\circ} \mathrm{C}$ in 2014 . Linear regression models (Fig. 3C) confirmed strong, positive correlations between canopy temperature and DWT for both 2013 and 2014 data $\left(R^{2}=0.82\right.$ and 0.94 , respectively).

Root biomass showed a moderately positive correlation with TQ and NDVI, $r=0.57$ and $r=0.68$, respectively, in 2013, but no correlation to these two variables were observed in 2014. A moderately negative correlation was observed between $\mathrm{RB}$ and $\mathrm{CT}$ $(r=-0.42)$ in 2013 , but this correlation was not evident in 2014. No significant differences in $\mathrm{RB}$ were found across mowing heights $(P=0.244)$; therefore, data were pooled for comparison at each soil moisture gradient level. Mean separation for RB with respect to DWT was performed separately for 2013 and $2014(P<0.001)$. Root biomass at $27-\mathrm{cm}$ DWT was lower than RB at $42.5-$ to $73.5-\mathrm{cm}$ DWT in 2013 and lower than all other levels in 2014. Root biomass was often lowest at droughty levels (120- to 151-cm DWT) of the tanks, regardless of experimental run. Linear regression models predicting $\mathrm{RB}$ with respect to DWT for 2013 and 2014 are shown in Fig. $3 \mathrm{D}\left(R^{2}=0.42\right.$ and 0.22 , respectively).

\section{Discussion}

Utilization of water-table depth gradient tanks allowed for trial conductance without rooting constraint concerns typically observed in greenhouse pot studies or environmental impacts associated with LGIS. Potential for root restriction was reduced because turfgrass 
plants were grown in large volumes of soil $\left(4 \mathrm{~m}^{3}\right)$, therefore allowing 3 months of trial duration. Excavation of each tank to determine capillary rise confirmed an even distribution of moisture throughout the soil profile. Nevertheless, space limitations, labor, challenges associated with establishing turfgrass on sloped surfaces, and material needed for tank construction may limit experimental use and adoption of this technique in greenhouses. Typically, plant position within each moisture level row should affect intraspecific plant competition and resource acquisition; however, differences in turfgrass growth along tank edges with fewer neighboring plants were not apparent.

Mowing height did not have an effect on either turfgrass species growth or plant health response to soil moisture levels. Although higher mowing heights are often associated with more robust, vigorous root systems (Christians et al., 2016), the accumulation of more canopy tissue can increase evapotranspiration rates and plant water requirements (Biran et al., 1981; Feldhake et al., 1983; Feldhake et al., 1984). Burns (1976) saw no effect of mowing height on the water consumption of tall fescue (Festuca arundinacea Schreb.), whereas Biran et al. (1981) observed a temporary increase $(\approx 6$ weeks) in turfgrass vigor by increasing the height of common bermudagrass [Cynodon dactylon (L.) Pers.] and manilagrass. Wherley et al. (2014) reported that mowing height $(1.3,2.5$, and $5.1 \mathrm{~cm})$ did not significantly influence irrigation requirements of any bermudagrass cultivars evaluated in a LGIS study, including 'Tifway 419'. However, 'Zeon' manilagrass maintained at $1.3 \mathrm{~cm}$ exhibited greater TQ with less irrigation compared with the same species maintained at 5.1 $\mathrm{cm}$ (Wherley et al., 2014). It was theorized that manilagrass thatch accumulation was greater at higher mowing heights; therefore, reducing rooting depth and water infiltration leading to reduced turfgrass tolerance to deficit irrigation and drought. This trend was not consistent among all manilagrass cultivars examined and did not occur among Japanese lawngrass (Zoysia japonica Steud.) cultivars in the same trial. Culpepper et al. (2020) did not observe a significant mowing height (5 and $9 \mathrm{~cm}$ ) response when comparing NDVI and TQ of 'Celebration' common bermudagrass and 'Zeon' manilagrass subjected to natural rainfall vs. supplemental irrigation.

Our findings suggest a correlation between hybrid bermudagrass success and high soil moisture content. Turfgrass quality, NDVI, and $\mathrm{RB}$ were greatest and $\mathrm{CT}$ was lowest at the lower, wetter levels (27- to 58-cm DWT) of each gradient tank where plants were continuously growing at or above field capacity for the duration of the study. Tan et al. (2010) noted that bermudagrass can endure waterlogged conditions through lower metabolic activity, high carbohydrate reserves, and detoxification of activated oxygen species. Changes in bermudagrass morphology when subjected to high soil moisture may provide insight into its ability to perform well under those conditions. Tan et al. (2013) reported that bermudagrass develops aerenchyma tissue, air channels that allow for gas exchange between roots and shoots, in response to waterlogged conditions. It is important to note that bermudagrass plants at $27-\mathrm{cm}$ DWT in our research were only subjected to high soil moisture and not submergence, which could explain high RB production at the low end of the gradient tanks. Although TQ and NDVI for manilagrass were greatest at the lower, wetter levels (27- to 58$\mathrm{cm}$ DWT) of each gradient tank, RB at $27-\mathrm{cm}$ DWT was lower than RB at $42.5-$ to $73.5-\mathrm{cm}$ DWT in 2013 and lower than all other levels in 2014. Zoysia spp. prefer well-drained soils (Christians et al., 2016; Emmons, 2000); therefore, high soil moisture content at the lowest level of the tank may be responsible for limitations in RB production.

In a similar water-table depth gradient tank experiment, Henry et al. (2009) observed a decrease in 'Tifway 419' hybrid bermudagrass survival above level 4 (73.5-cm DWT) 3 months after trial initiation when grown in sand and sandy loam soil. Greater survival and TQ in our study may be attributed to the use of a sandy clay loam soil with higher moisture retention and capillary rise. Hybrid bermudagrass TQ was 3.5 to 4.5 in 2013 and 1.3 to 3.0 in 2014 in the droughty levels $(120-$ to $151-\mathrm{cm}$ DWT) $(0 \%$ VWC in the upper $7.6 \mathrm{~cm}$ of soil) of the gradient tanks. Steinke et al. (2011) observed similar TQ (3 and 4.5) of 'Tifway $419^{\prime}$ hybrid bermudagrass after 55 and $61 \mathrm{~d}$ of drought, respectively. Wherley et al. (2014) observed TQ of 3.5 to 4.0 for 'Tifway 419' during the spring after summer drought. Although hybrid bermudagrass RB decreased as DWT increased, RB was similar from 73.5to $151-\mathrm{cm}$ DWT. Manilagrass TQ was 1.8 to 2.7 in the droughty levels $(120-$ to $151-\mathrm{cm}$ DWT) of the gradient tanks. Although Wherley et al. (2014) noted that manilagrass required more supplemental irrigation to maintain acceptable quality $(>6.0)$, TQ of nonirrigated 'Zeon' was 4.1 to 6.0 , regardless of mowing height. Wherley et al. (2014) also noted that 'Zeon' manilagrass exhibited shallower roots. This was only evident in our research in 2013. Similarly, Zhang et al. (2019) also observed greater 'Celebration' common bermudagrass root length (1067 to $1239 \mathrm{~mm}$ ) at deeper soil depths (30 to $90 \mathrm{~cm}$ ) compared with 'Zeon' manilagrass (109 to $186 \mathrm{~mm}$ ) following a 21-d dry-down period. Several other studies have compared hybrid or common bermudagrass with Japanese lawngrass subjected to drought conditions. Qian and Engelke (1999) and Carrow (1996) ranked 'Tifway 419' hybrid bermudagrass higher than 'Meyer' Japanese lawngrass for drought resistance. Fu et al. (2004) theorized that 'Midlawn' bermudagrass could tolerate a lower relative leaf water content and higher level of electrolyte leakage before TQ declined to an unacceptable level (TQ < 6) compared with 'Meyer' Japanese lawngrass. Hybrid bermudagrass and manilagrass responded similarly to drought in our research. Comparably, Sifers et al. (1990) ranked bermudagrass and Zoysia spp. equal in a greenhouse drought study based on canopy leaf firing.
Significant year effects were observed for several measured variables in our research, regardless of turfgrass species; therefore, those data were presented separately for each experimental run. Bermudagrass exhibited higher TQ and lower CT in 2013 than 2014. In 2013, the experiment was conducted in the greenhouse during the summer when temperatures and light quality/quantity were more conducive to bermudagrass growth, whereas the second run of the experiment was conducted primarily during Winter 2014. Although this research was conducted in a temperature-controlled greenhouse and received supplemental light, the age and design of the complex may have made it difficult to maintain uniform light intensity and temperatures during winter months. Zoysiagrass did not exhibit significant year effects with respect to TQ and NDVI, which may be related to its tolerance of lower temperatures and shaded environments compared with bermudagrass.

Results of the present experiment demonstrate that hybrid bermudagrass and manilagrass respond relatively similarly to soil moisture stress. However, only one cultivar of each species were examined; therefore, additional research with several cultivars of each species may be necessary to further explain the range of potential response to soil moisture using this methodology. Furthermore, hybrid bermudagrass was relatively insensitive to high soil moisture, whereas manilagrass growth was suppressed under the same moisture conditions. Therefore, manilagrass may become less competitive when grown in low-lying areas, under reduced water infiltration, or in heavy clay soils. Both species exhibited reductions in plant health and growth when subjected to extended drought conditions. Consequently, management of either species should emphasize the increase of root depth and biomass to minimize the negative effects of reduced soil moisture. This may be accomplished through cultivation practicesthat alleviate thatch or soil compaction, use of phosphorus and potassium fertilizers, application of soil penetrants, and installation of proper drainage. Successful application of these water-table depth gradient tanks leads to the endorsement of their use for the investigation of niche differentiation, invasive species, and interspecific competition in response to soil moisture stress.

\section{Literature Cited}

Aronson, L.J., R.J. Hull, and A.J. Gold. 1987. Cool-season turfgrass responses to drought stress. Crop Sci. 27:1261-1266.

Biran, I., B. Bravdo, I. Bushkin-Harav, and E. Rawitz. 1981. Water consumption and growth rate of 11 turfgrasses as affected by mowing height, irrigation frequency, and soil moisture. Agron. J. 73:85-90.

Bivand, R. 1980. A Monte Carlo study of correlation coefficient estimation with spatially autocorrelated observations. Quaest. Geogr. 6:5-10.

Burns, R.E. 1976. Tall fescue turf as affected by mowing height. Agron. J. 68:274-276.

Carrow, R.N. 1996. Drought resistance aspects of turfgrasses in the southeast: Root-shoot responses. Crop Sci. 36:687-694. 
Christians, N.E., A.J. Patton, and Q.D. Law. 2016. Fundamentals of turfgrass management. 5th ed. Wiley, NJ.

Cliff, A.D. and J.K. Ord. 1981. Spatial processes: Models and applications. Pion Ltd., London.

Clifford, P., S. Richardson, and D. Hemon. 1989. Assessing the significance of the correlation between two spatial processes. Biometrics 45:123-134.

Culpepper, T., J. Young, and B. Wherley. 2020. Comparison of four warm-season turfgrass species to natural rainfall or supplemental irrigation in a semiarid climate. Agrosyst. Geosci. \& Environ. https://doi.org/10.1002/agg2.20011.

Dai, A. 2011. Drought under global warming: A review. Wiley Interdiscip. Rev. Clim. Change 2:45-65, doi: 10.1002/wcc.81.

Duble, R.L. 2001. Turfgrasses: Their management and use in the southern zone, Vol. 20. Texas A\&M University Press, TX.

Dutilleul, P. 1993. Modifying the t test for assessing the correlation between two spatial processes. Biometrics 49:305-314.

Emmons, R. 2000. Turfgrass science and management. 3rd ed. Delmar, New York.

Feldhake, C.M., R.E. Danielson, and J.D. Butler. 1983. Turfgrass evapotranspiration. I. Factors influencing rate in urban environments. Agron. J. 75:824-830.

Feldhake, C.M., J.D. Butler, and R.E. Danielson. 1984. Turfgrass evapotranspiration. II. Responses to deficit irrigation. Agron. J. 76:85-89.

Fry, J. and B. Huang. 2004. Applied turfgrass science and physiology. Wiley, NJ.

Fu, J.M., J. Fry, and B.R. Huang. 2004. Minimum water requirements of four turfgrasses in the transition zone. HortScience 39:1740-1744.

Garrot, D.J., Jr. and C.F. Mancino. 1994. Consumptive water use of three intensively managed bermudagrasses growing under arid conditions. Crop Sci. 34:215-221.

Harivandi, M.A. and V. Gibeault. 1990. Managing turfgrasses during drought. Calif. Turfgrass Cult. 40:1-2.

Hays, K.L., J.F. Barber, M.P. Kenna, and T.G. McCollum. 1991. Drought avoidance mechanisms of selected bermudagrass genotypes. HortScience 26:180-182.

Henry, G.M., F.H. Yelverton, and M.G. Burton. 2009. Asymmetric responses of Paspalum species to a soil moisture gradient. Crop Sci. 49: 1473-1480.

Hook, J.E. and W.W. Hanna. 1994. Drought resistance in centipedegrass cultivars. HortScience 29:1528-1531.

Huang, B., R.N. Carrow, and R.R. Duncan. 1997a. Drought-resistance mechanisms of seven warmseason turfgrasses under surface soil drying. I. Shoot response. Crop Sci. 37:1858-1863.
Huang, B., R.N. Carrow, and R.R. Duncan. 1997b. Drought-resistance mechanisms of seven warmseason turfgrasses under surface soil drying. II. Root aspects. Crop Sci. 37:1863-1869.

Huang, B. and H. Gao. 2000. Root physiological characteristics associated with drought resistance in tall fescue cultivars. Crop Sci. 40:196-203.

Kneebone, W.R. and I.L. Pepper. 1982. Consumptive water use by sub-irrigated turfgrasses under desert conditions. Agron. J. 74:419-423.

Krizek, D.T., A. Carmi, R.M. Mirecki, F.W. Snyder, and J.A. Bunce. 1985. Comparative effects of soil moisture stress and restricted root zone volume on morphogenetic and physiological responses of soybean [Glycine max (L.) Merr.]. J. Expt. Bot. 36:25-38.

Manuel, J. 2008. Drought in the southeast: Lessons for water management. Environ. Health Perspect. 116:A168-A171.

Marcum, K.B., M. Engelke, S.J. Morton, and R.H. White. 1995. Rooting characteristics and associated drought resistance of zoysiagrasses. Agron. J. 87:534-538.

McCarty, L.B., T.G. Willis, J.E. Toler, and T. Whitwell. 2011. 'TifEagle' bermudagrass response to plant growth regulators and mowing height. Agron. J. 103:988-994, doi: 10.2134/ agronj2010.0467.

Meyer, J.L. and V.A. Gibeault. 1986. Turfgrass performance under reduced irrigation. Calif. Agr. 40:8.

Morris, K.N. and R.C. Shearman. 2007. NTEP turfgrass evaluation guidelines. National Turfgrass Evaluation Program, Beltsville, MD. 18 Apr. 2020. <http://www.ntep.org/pdf/rat-ings.pdf>.

Mueller-Dombois, D. 1965. Technique for studying soil-water-growth relation on an artificial slope, p. 153-161. In: Forest-soil relationships in North America. Oregon State Univ. Press, OR.

Mueller-Dombois, D. and H. Sims. 1966. Response of three grasses to two soils and a water table depth gradient. Ecology 47:644-648.

Plaut, Z., A. Grava, and A. Carmi. 1996. Cotton root and shoot responses to subsurface drip irrigation and partial wetting of the upper soil profile. Irrig. Sci. 16:107-113.

Qian, Y. and M. Engelke. 1999. Performance of five turfgrasses under linear gradient irrigation. HortScience 34:893-896.

Qian, Y. and J.D. Fry. 1997. Water relations and drought tolerance of four turfgrasses. J. Amer. Soc. Hort. Sci. 122:129-133.

Qian, Y.L., W.S. Upham, and J.D. Fry. 1997. Rooting and drought avoidance of warm-season turfgrasses and tall fescue in Kansas. Crop Sci. 37:905-910.

Seager, R., A. Tzanova, and J. Nakamura. 2009. Drought in the southeastern United States: Causes, variability over the last millennium, and the potential for future hydroclimate change. J.
Clim. 22:5021-5045, doi: 10.1175/2009JCL12 683.1 .

Serena, M., M. Schiavon, R. Sallenave, and B. Leinauer. 2020. Drought avoidance of warmseason turfgrasses affected by irrigation system, soil surfactant revolution, and plant growth regulator trinexapac-ethyl. Crop Sci. 60:485-498, doi: $10.1002 / \csc 2.20063$.

Shahba, M.A., M.S. Abbas, and S.F. Alshammary. 2014. Drought resistance strategies of seashore paspalum cultivars at different mowing heights HortScience 49:221-229, doi: 10.21273/HORT SCI.49.2.221

Sifers, S.I., J.B. Beard, and M.H. Hall. 1990. Comparative dehydration avoidance and drought resistance among major warm-season turfgrass species and cultivars. Texas Turfgrass Research1990. PR-4738-4768. Texas Agr. Expt. Sta. Publ., College Station.

Steinke, K., D. Chalmers, J. Thomas, and R. White. 2011. Bermudagrass and buffalograss drought response and recovery at two soil depths. Crop Sci. 51:1215-1223, doi: 10.2135/ cropsci2010.08.0469.

Tan, S., Z. Mingyong, and Q. Zhang. 2010. Physiological responses of bermudagrass (Cynodon dactylon) to submergence. Acta Physiol. Plant. 32:133-140, doi: 10.1007/s11738-009-0388-7.

Tan, S., Z. Mingyong, K. Zhang, and H. Xu. 2013. Effects of submergence on morpho- physiological characteristics and recovery of bermudagrass (Cynodon dactylon). Fresenius Environ. Bull. 22:2533-2541.

Turgeon, A.J. 2011. Turfgrass management. 9th ed. Prentice Hall, NJ.

Wherley, B., J. Heitholt, A. Chandra, and P. Skulkaew. 2014. Supplemental irrigation requirements of zoysiagrass and bermudagrass cultivars. Crop Sci. 54:1823-1831, doi: 10.2135/cropsci 2013.11.0753.

Zhang, J., B. Poudel, K. Kenworthy, J.B. Unruh, D. Rowland, J.E. Erickson, and J. Kruse. 2019. Drought responses of above-ground and belowground characteristics in warm-season turfgrass. J. Agron. Crop Sci. 205:1-12, doi: 10.1111/jac. 12301

Zhang, J., J.B. Unruh, and K. Kenworthy. 2013. Zoysiagrass cultivar responses under a linear gradient irrigation system. Intl. Turfgrass Soc. Res. J. 12:179-186.

Zhang, J., J.B. Unruh, and K. Kenworthy. 2015. Turf performance of bahiagrass, centipedegrass, and St. Augustinegrass cultivars under a linear gradient irrigation system. HortScience 50: 491-495, doi: 10.21273/HORTSCI.50.3.491.

Zhou, Y., C.J. Lambrides, R. Kearns, C. Ye, and S. Fukai. 2012. Water use, water use efficiency and drought resistance among warm-season turfgrasses in shallow soil profiles. Funct. Plant Biol. 39:116-125, doi: 10.1071/FP11244. 